doc. dr. sc. Ana Ježovita

Sveučilište u Zagrebu, Ekonomski fakultet, Katedra za računovodstvo, Zagreb, Hrvatska

ajezovita@efzg.hr

Petra Halar, mag. oec.

Sveučilište u Zagrebu, Ekonomski fakultet, Katedra za računovodstvo, Zagreb, Hrvatska

phalar@efzg.hr

prof. dr. sc. Boris Tušek

Sveučilište u Zagrebu, Ekonomski fakultet, Katedra za računovodstvo, Zagreb, Hrvatska

btusek@efzg.hr

\title{
UČINCI IMPLEMENTACIJE MSFI-JA 15 PRIHODI NA TEMELJU UGOVORA S KUPCIMA NA TRANSPARENTNOST FINANCIJSKOG IZVJEŠTAVANJA PODUZEĆA U REPUBLICI HRVATSKOJ
}

Primljen: 1. kolovoza 2021.

Prihvaćen: 15. listopada 2021.

https://doi.org/10.46458/27121097.2021.27.72

Prethodno priopéenje

\section{Sažetak}

Prihodi kao povećanje ekonomskih koristi u obliku povećanja imovine ili smanjenja obveza u fokusu su upravljanja poslovanjem svakog profitnog poduzeća. Radi se o elementu financijskih izvještaja koji je ključan za ocjenu uspješnosti poslovanja poduzeća. Ostvarenje ciljeva poslovanja najvećeg broja poduzeća vrednuje se izravno kroz razinu ostvarenih prihoda ili neizravno kroz druge financijske pokazatelje kao što su rentabilnost ukupne imovine, marža profita, zarade prije kamata, operativna dobit, a koji se temelje na prihodima. S aspekta eksternih interesno-utjecajnih skupina, značaj prihoda vidljiv je kroz izvješća neovisnih revizora gdje je priznavanje prihoda istaknuto kao ključno revizijsko pitanje za 
27\% kotirajućih poduzeća u Republici Hrvatskoj za 2019. godinu. U kontekstu sagledavanja prihoda kao neophodne podloge u procesu poslovnog odlučivanja važno je pitanje njihovog priznavanja u poslovnim knjigama poduzeća. S ciljevima pružanja robusnijeg okvira priznavanja prihoda, osiguravanja usporedivosti među industrijama, tržištima kapitala, gospodarskom okruženju, te pružanja relevantnih informacija korisnicima financijskih izvještaja u pogledu zahtjeva za objavljivanjem u bilješkama uz financijske izvještaje, Odbor za Međunarodne računovodstvene standarde 2014. godine usvojio je novi računovodstveni standard kojim je uređeno priznavanje prihoda iz ugovora s kupcima kao i zahtjevi za objavljivanje dostatnih informacija u bilješkama uz financijske izvještaje, a kako bi se korisnicima financijskih izvještaja omogućilo razumijevanje vrste, iznosa, vremenskog okvira i neizvjesnosti prihoda i novčanih tokova proizišlih iz ugovora s kupcima. Nakon dvije godine primjene MSFI-ja 15 Prihodi na temelju ugovora s kupcima pitanje je koji su učinci Standarda na objavu kvalitativnih i kvantitativnih informacija u bilješkama uz financijske izvještaje te jesu li transparentnija i robusnija pravila priznavanja prihoda rezultirala promjenama u iskazivanju informacija o uspješnosti poslovanja poduzeća? U skladu s navedenim pitanjima, cilj rada je istražiti i ocijeniti učinke primjene MSFI-ja 15 Prihodi na temelju ugovora s kupcima na kvalitativna poboljšanja informativne vrijednosti objava $u$ vezi prihoda u bilješkama uz financijske izvještaje na primjeru poduzeća u Republici Hrvatskoj. Pored toga, cilj rada je za isti uzorak poduzeća ocijeniti kvantitativne učinke primjene Standarda na razinu prezentiranih prihoda. Uzorak poduzeća obuhvaća četrdesetak poduzeća onih industrija za koje je ocijenjeno da je učinak primjene novog Standarda najznačajniji (npr. telekomunikacije, građevinarstvo, brodogradnja), a prikupljeni podaci analizirani su metodom analize sadržaja i drugim primjenjivim metodama inferencijalne statistike.

Ključne riječi: priznavanje prihoda, MSFI 15, ugovori s kupcima, uspješnost, bilješke uz financijske izvještaje

JEL: M41

\section{UVOD}

Suvremeno doba obilježavaju izrazito kompleksni, dinamični, neizvjesni, nestabilni, odnosno općenito, kaotični uvjeti poslovanja. Kako bi upravljačke strukture u takvom okruženju mogle donositi racionalne poslovne odluke, upravljati i nadzirati poslovanje poduzeća na dnevnoj bazi, a sve u cilju osiguranja sigurnosti i povećanja uspješnosti poslovanja u dugom roku, potrebna im je kvalitetna informacijska podloga. Također, za kvalitetne informacije o poslovanju poduzeća, zainteresirane su i ostale interne, kao i eksterne interesno-utjecajne skupine. 
Tradicionalno, prilikom razmatranja informacija potrebnih za racionalno poslovno odlučivanje, naglasak je bio primarno na financijskim informacijama, kao rezultatu procesa financijskog izvještavanja. Iako se danas sve više govori o procesu tzv. integriranog izvještavanja, odnosno kombinaciji financijskog i nefinancijskog izvještavanja, informacije o poslovanju poduzeća sadržane u temeljnim financijskim izvještajima uvijek će biti važne, samo što će se u budućnosti još više povećavati transparentnost izvještavanja o svim, a ne samo financijskim ili ekonomskim aspektima poslovanja poduzeća kroz prikazivanje dodatnih nefinancijskih informacija o društvenoj odgovornosti, održivosti poslovanja, i slično. Za sastavljanje kvalitetnih financijskih izvještaja, koji podliježu obvezi javne objave, nužno je primjenjivati odgovarajuća pravila financijskog izvještavanja, a posebice računovodstvena načela, računovodstvene standarde i zakonske propise, kao i odgovarajuće nadzirati taj proces. S obzirom da se uslijed suvremenih, kaotičnih eksternih uvjeta, poslovanje poduzeća radikalno mijenja, nužno je da te promjene prate i okviri izvještavanja, a posebice Međunarodni standardi financijskog izvještavanja (dalje u tekstu: MSFI), kao ključna računovodstvena osnova koja je prihvaćena od velikog broja zemalja, bilo kao osnovni standardi, bilo kao temelj za oblikovanje vlastitih, nacionalnih standarda. „Problematika koju obrađuju standardi vrlo je složena i upravo zbog te složenosti i promjena koje se događaju u suvremenom poslovanju i okruženju poduzeća jednom utvrđeni standardi nisu zauvijek dani, već se sukladno promjenama u poslovnom okruženju mijenjaju i njihove odrednice“ (Žager, et al., 2016., 147). Razlozi zbog kojih se mijenjaju međunarodni i/ili nacionalni računovodstveni standardi su, primjerice, sljedeći (Pavić, 2018., 199-200):

- harmonizacija financijskog izvještavanja na međunarodnoj razini

- kvalitetno izvještavanje poduzeća zahtijevano od strane svjetskih organizacija $\mathrm{i}$ institucija

- suradnja s regulatorima tržišta kapitala radi povećanja zaštite investitora, odnosno dioničara poduzeća

- problemi uslijed interpretacije i primjene određenih Standarda prilikom sastavljanja financijskih izvještaja

- nedorečenost pojedinih zahtjeva Standarda i njihova neprilagođenost suvremenim uvjetima poslovanja.

Posljednje promjene strukture i sadržaja MSFI-ja vezane su uz uvođenje četiri nova Standarda, koji imaju značajan utjecaj na proces financijskog izvještavanja poduzeća, a odnose se na računovodstveni tretman financijskih instrumenata, prihoda od ugovora s kupcima, najmova te ugovora o osiguranju. 
U ovom radu naglasak je na razmatranju učinaka uvođenja i primjene MSFI-ja 15 Prihodi na temelju ugovora s kupcima na transparentnost financijskog izvještavanja poduzeća, s obzirom na važnost i značaj prihoda kao jedne od temeljnih odrednica profitabilnosti, odnosno u širem smislu, uspješnosti poslovanja poduzeća. Stoga su se postavila sljedeća dva istraživačka pitanja:

- koji su učinci implementacije MSFI-ja 15 Prihodi na temelju ugovora s kupcima na objavu kvalitativnih i kvantitativnih informacija u bilješkama uz financijske izvještaje, te

- jesu li transparentnija i robusnija pravila priznavanja prihoda rezultirala promjenama u iskazivanju informacija o uspješnosti poslovanja poduzeća?

- Na temelju postavljenih istraživačkih pitanja, definirani su i sljedeći istraživački ciljevi:

- istražiti i ocijeniti učinke uvođenja i primjene MSFI-ja 15 Prihodi na temelju ugovora s kupcima na kvalitativna poboljšanja informativne vrijednosti objava u vezi prihoda u bilješkama uz financijske izvještaje, te

- ocijeniti kvantitativne učinke uvođenja i primjene MSFI-ja 15 Prihodi na temelju ugovora s kupcima na razinu prezentiranih prihoda.

Rad se sastoji od šest dijelova. Nakon uvoda, u drugom dijelu se analizira i objašnjava nužnost razvoja, ključne pretpostavke i zahtjevi MSFI-ja 15 Prihodi na temelju ugovora s kupcima, kao i ključne promjene koje su nastale u procesu financijskog izvještavanja uzrokovane njegovom implementacijom. Nakon toga, $\mathrm{u}$ trećem dijelu rada se daje pregled relevantne literature i rezultata postojećih istraživanja, kao temelj za provođenje daljnjeg empirijskog istraživanja. U četvrtom dijelu se objašnjavaju metodologija istraživanja i izvori podataka, a u petom dijelu rada prikazuju i interpretiraju rezultati istraživanja. Na kraju u šestom dijelu predočeni su zaključci rada.

\section{OKVIR PRIZNAVANJA I MJERENJA PRIHODA PREMA MSFI-ju 15 PRIHODI NA TEMELJU UGOVORA S KUPCIMA}

Cilj poslovanja svakog poduzeća je osigurati opstanak na tržištu u dugom roku, dok je uz to cilj poslovanja svakog profitno orijentiranog poduzeća osigurati i profitabilno poslovanje (Žager, et al., 2017., 9). Profitabilno poslovanje ili poslovanje s dobiti znači da poduzeća uspijevaju prodavati proizvode, odnosno pružati 
usluge, po višoj prodajnoj vrijednosti od troškova njihove proizvodnje, nabave ili pružanja. Pri tome, poduzeća nastoje maksimizirati ostvarenu dobit, na način da razlika između ostvarenih prihoda i rashoda bude što je moguće veća. Iz toga se može zaključiti kako su prihodi ostvareni iz osnovne djelatnosti poduzeća, odnosno temeljem prodaje proizvoda i pružanja usluga, zapravo prva komponenta funkcije dobiti (Žager, et al., 2017., 9). S obzirom na to, prihodi predstavljaju značajnu stavku u financijskim izvještajima poduzeća te su kao takvi podložni različitim vrstama računovodstvenih manipulacija, stoga je ključno poznavati pravila priznavanja i mjerenja prihoda te ih, vodeći se načelom opreznosti, odgovarajuće i primjenjivati (Žager, et al., 2016., 171).

MSFI koji utvrđuje načela i pravila koja poduzeća trebaju ,primjenjivati radi izvještavanja korisnika financijskih izvještaja o korisnim informacijama u pogledu vrste, iznosa, vremenskog okvira i neizvjesnosti prihoda i novčanih tokova koji proizlaze iz ugovora s kupcem“ (Uredba Komisije (EU) 2016/1905) je MSFI 15 Prihodi na temelju ugovora s kupcima. Konačna verzija MSFI 15 je izdana u svibnju 2014. godine, kao rezultat zajedničke suradnje Odbora za međunarodne računovodstvene standarde (engl. International Accounting Standards Board $I A S B$ ) i Odbora za financijske računovodstvene standarde (engl. Financial Accounting Standards Board - FASB) (Deloitte, 2020., 3). Navedeni Standard stupio je na snagu 1. siječnja 2018. godine, a njegovo donošenje podrazumijevalo je izmjene MSFI-jeva 1, 3 i 4, Međunarodnih računovodstvenih standarda (u daljnjem tekstu: MRS) 1, 2, 12, 16, 32, 34, 36, 37, 38, 39 i 40, Tumačenja Odbora za tumačenje međunarodnih standarda financijskog izvještavanja (u daljnjem tekstu: OTMSFI) 12, Tumačenja Stalnog odbora za tumačenja (u daljnjem tekstu: SIC) 27 i 32, kao i povlačenje MRS-ova 11 i 18, OTMSFI-ja 13, 15 i 18 te SIC-a 31 (Uredba Komisije (EU) 2016/1905). Donošenjem MSFI-ja 15 nastojalo se je „poboljšati financijsko izvještavanje o prihodima i usporedivost gornje linije $u$ financijskim izvještajima na globalnoj razini“ (Europska komisija, 2015.). Prema tome, MSFI 15 Prihodi na temelju ugovora s kupcima predstavlja jedinstveni sveobuhvatni okvir koji poduzeća trebaju koristiti za računovodstveno priznavanje i mjerenje prihoda od ugovora s kupcima, te koji zamjenjuje većinu prijašnjih smjernica vezanih uz prihode, uključujući i industrijski specifične smjernice (Deloitte, 2020., 3). Također, Standardom se pridonosi objavljivanju većeg broja informacija o prihodima, pružaju smjernice za transakcije koje prethodno nisu bile sveobuhvatno pokrivene te unaprjeđuju smjernice za aranžmane s višestrukim elementima (Europska komisija, 2015.).

Prema temeljnom načelu MSFI-ja 15, poduzeća trebaju priznati prihode u iznosima koji odražavaju naknade koje poduzeća očekuju primiti u zamjenu za isporučene ili prenesene proizvode ili usluge kupcima (Uredba Komisije (EU) 2016/1905). Temeljnim načelom, koje su zajednički definirali Odbor za 
međunarodne računovodstvene standarde i Odbor za financijske računovodstvene standarde, odgovoreno je na dva ključna pitanja vezana uz priznavanje i mjerenje prihoda koja se odnose na vrijeme i iznos priznavanja prihoda (Tablica 1) (Deloitte, 2020., 3).

Tablica 1. Vrijeme i iznos priznavanja prihoda prema MSFI-ju 15 Prihodi na temelju ugovora s kupcima

\begin{tabular}{|c|c|}
\hline PITANJE & ODGOVOR \\
\hline $\begin{array}{c}\text { Kada poduzeća mogu pri- } \\
\text { znati prihode? }\end{array}$ & $\begin{array}{c}\text { Kada poduzeća ispune svoje obveze temeljem ugovora } \\
\text { isporučivanjem ili prijenosom proizvoda ili usluga kupci- } \\
\text { ma. Drugim riječima, kada poduzeća obave svoju osnovnu } \\
\text { poslovnu aktivnost, tada bi trebala priznati prihode. }\end{array}$ \\
\hline $\begin{array}{c}\text { Koliko prihoda poduzeća } \\
\text { mogu priznati? }\end{array}$ & $\begin{array}{c}\text { Poduzeća mogu priznati prihode u iznosima za koje oče- } \\
\text { kuju da će imati pravo na njih prema ugovorima (tj. oče- } \\
\text { kivani iznosi, za koje je potrebno primijeniti odgovarajuće } \\
\text { procjene). }\end{array}$ \\
\hline
\end{tabular}

Izvor: (Deloitte, 2020., 3-4).

Standard se odnosi na sve ugovore s kupcima, osim (Uredba Komisije (EU) 2016/1905; BDO, 2021., 1):

- ugovora o najmu (područje primjene MSFI 16 Najmovi)

- ugovora o osiguranju (područje primjene MSFI-ja 4 Ugovori o osiguranjul MSFI-ja 17 Ugovori o osiguranju)

- financijskih instrumenata i drugih ugovornih prava ili obveza (područje primjene MSFI-ja 9 Financijski instrumenti, MSFI-ja 10 Konsolidirani financijski izvještaji, MSFI-ja 11 Zajednički poslovi, MRS-a 27 Nekonsolidirani financijski izvještaji i MRS-a 28 Udjeli u pridruženim subjektima $i$ zajedničkim pothvatima)

- nenovčanih razmjena između poduzeća koja obavljaju istu poslovnu aktivnost kako bi se olakšala prodaja kupcima ili potencijalnim kupcima.

Prema MSFI-ju 15 Prihodi na temelju ugovora s kupcima temeljni okvir modela priznavanja prihoda čini pet koraka koji su prikazani na Slici 1. 
Slika 1. Model 'pet koraka' priznavanja prihoda prema MSFI-ju 15 Prihodi na temelju ugovora s kupcima
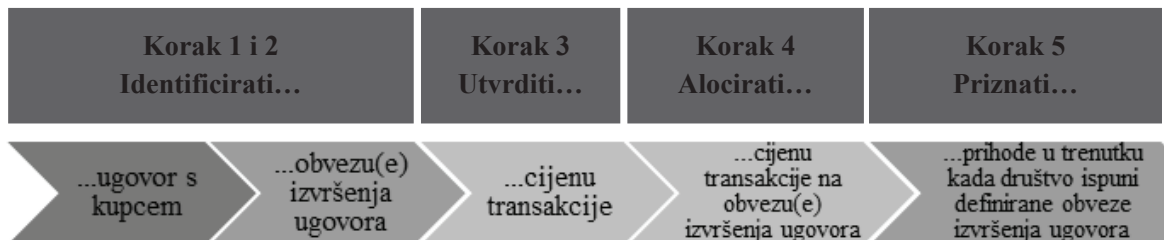
definirane obveze izvršenja ugovora

Izvor: (BDO, 2021., 1).

Za bolje razumijevanje i primjenu MSFI-ja 15 Prihodi na temelju ugovora s kupcima neophodno je razumjeti pojmove i definicije prikazane u Tablici 2.

Tablica 2. Ključni pojmovi i definicije MSFI-ja 15 Prihodi na temelju ugovora s kupcima

\begin{tabular}{|c|c|}
\hline POJAM & DEFINICIJA \\
\hline Ugovor & $\begin{array}{l}\text { sporazum između dviju ili više stranaka kojim nastaju ostvariva } \\
\text { prava i izvršive obveze }\end{array}$ \\
\hline Kupac & $\begin{array}{c}\begin{array}{c}\text { stranka koja je s poduzećem sklopila ugovor o nabavi proizvoda } \\
\text { ili usluga koje su rezultat redovnog poslovanja poduzeća u za- } \\
\text { mjenu za naknadu }\end{array} \\
\end{array}$ \\
\hline Prihod & $\begin{array}{l}\text { povećanja ekonomskih koristi tijekom računovodstvenog raz- } \\
\text { doblja u obliku priljeva ili povećanja imovine ili smanjenja ob- } \\
\text { veza, što ima za posljedicu povećanje vlasničkog kapitala, osim } \\
\text { povećanja povezanih s uplatama sudionika u kapitalu } \\
\text { prihod nastao tijekom redovnog poslovanja poduzeća }\end{array}$ \\
\hline Obveza na činidbu & $\begin{array}{c}\text { obećanje u ugovoru s kupcem u pogledu prijenosa kupcu: } \\
\text { različitih proizvoda ili usluga (ili paketa proizvoda ili usluga) il } \\
\text { niza različitih proizvoda ili usluga koje su u znatnoj mjeri iste i } \\
\text { imaju isti obrazac prijenosa kupcu }\end{array}$ \\
\hline $\begin{array}{l}\text { Samostalna prodajna } \\
\text { cijena (proizvoda ili } \\
\text { usluge) }\end{array}$ & $\begin{array}{c}\text { cijena po kojoj bi poduzeće obećani proizvod ili uslugu zasebno } \\
\text { prodao kupcu }\end{array}$ \\
\hline $\begin{array}{l}\text { Cijena transakcije } \\
\text { (za ugovor s kup- } \\
\text { cem) }\end{array}$ & $\begin{array}{l}\text { iznos naknade na koju poduzeće očekuje da ima pravo u zamje- } \\
\text { nu za prijenos obećanih proizvoda ili usluga kupcu, isključujući } \\
\text { iznose prikupljene u ime trećih strana }\end{array}$ \\
\hline
\end{tabular}

Izvor: (Uredba Komisije (EU) 2016/1905; BDO, 2021., 1).

MSFI 15 Prihodi na temelju ugovora s kupcima značajno povećava broj potrebnih objava koje se zahtijevaju od poduzeća, s nekim potpuno novim zahtjevima 
(Davern, et al., 2019., 52). Cilj zahtjeva vezanih uz objavljivanje informacija je taj da poduzeće „objavi dostatne informacije kako bi se korisnicima financijskih izvještaja omogućilo razumijevanje vrste, iznosa, vremenskog okvira i neizvjesnosti prihoda i novčanih tokova proizišlih iz ugovora s kupcima" (Uredba Komisije (EU) 2016/1905). Da bi se taj cilj ostvario, poduzeće treba objavljivati kvalitativne i kvantitativne informacije o (Uredba Komisije (EU) 2016/1905):

- ugovorima s kupcima

- važnim prosudbama i promjenama prosudbi nastalim pri primjeni MSFI-ja 15 na te ugovore, $\mathrm{i}$

- svoj imovini priznatoj iz troškova stjecanja ili ispunjavanja ugovora s kupcem.

Također, poduzeće je sukladno MSFI-ju 15 dužno raščlanjivati prihode iz ugovora s kupcima u ,kategorije kojima se prikazuje na koji način gospodarski čimbenici utječu na vrstu, iznos, vremenski okvir i neizvjesnost prihoda i novčanih tokova" (Uredba Komisije (EU) 2016/1905). Primjeri nekih od kategorija su vrsta proizvoda ili usluga, zemljopisna regija, tržište ili vrsta kupca, vrsta ugovora, trajanje ugovora, vremenski raspored prijenosa robe ili usluga, te prodajni kanali“ (Uredba Komisije (EU) 2016/1905). Što se tiče prezentiranja informacija, poduzeća su dužna u izvještaju o financijskom položaju prezentirati odvojeno ugovornu imovinu i ugovorne obveze, dok su u računu dobiti i gubitka te u izvještaju o ostaloj sveobuhvatnoj dobiti dužna prezentirati odvojeno prihode te amortizaciju i umanjenje vrijednosti sukladno MRS 1 Prezentiranje financijskih izvještaja (BDO, 2021., 8).

\section{PREGLED LITERATURE}

Složenost zahtjeva i brojne novine koje su uvedene MSFI-jem 15 Prihodi na temelju ugovora s kupcima značajno su utjecale i utječu na poslovanje i financijsko izvještavanje poduzeća. Implementacija zahtjeva MSFI-ja 15 je značajno utjecala na promjenu filozofije priznavanja prihoda, ne samo kako bi se realno i objektivno prikazali prihodi poduzeća, već i kako bi se spriječilo korištenje prihoda za svrhe upravljanja zaradama, odnosno računovodstvenih manipulacija (Napier \& Stadler, 2020., 474). Implementacija MSFI-ja 15 je stvorila brojne izazove, kako za korisnike financijskih izvještaja, tako i za revizore, kojima su potrebne dodatne smjernice za njegovo uspješnije razumijevanje (Boujelben $\&$ Kobbi-Fakhfakh, 2020., 709). Promjene uvedene MSFI-jem 15 ne utječu na sve transakcije povezane s priznavanjem i mjerenjem prihoda, već su primarno 
ograničene na ugovore s kupcima, pa stoga nisu sva poduzeća, odnosno sve industrije pod utjecajem novog Standarda (Brozović \& Pavić, 2018., 1008), već samo industrije s određenim specifičnostima poslovanja. Industrije koje su pod značajnim utjecajem i učinkom MSFI-ja 15 na transparentnost njihovog financijskog izvještavanja, odnosno čiji zahtjevi značajno utječu na promjene u priznavanju i mjerenju prihoda, su primarno telekomunikacijska industrija, industrija zabave i medija, maloprodaja, automobilska industrija, softverska industrija, poslovanje nekretninama i građevinarstvo, energetika i komunalne djelatnosti, industrija putovanja, ugostiteljstva i razonode, zrakoplovstvo i obrana (Brozović \& Pavić, 2018., 1008). S obzirom na to, postoje određeni znanstveni i stručni radovi (Brozović \& Pavić, 2018.; Pavić, 2018.; Davern, et al., 2019.; Boujelben \& Kobbi-Fakhfakh, 2020.; Ergüden, 2020; Harris, 2020.; Napier \& Stadler, 2020.; Vaicekauskas, 2020.; van Wyk \& Coetsee, 2020.) koji su razmatrali te teorijski analizirali ili empirijski istraživali utjecaj MSFI-ja 15 Prihodi na temelju ugovora s kupcima na poslovanje i financijsko izvještavanje poduzeća koja spadaju u navedene industrije.

Autorice Brozović \& Pavić (2018.) su s ciljem analiziranja mogućih kratkoročnih i dugoročnih učinaka implementacije MSFI-ja 15 Prihodi na temelju ugovora s kupcima na priznavanje prihoda, odnosno na financijski položaj i uspješnost poslovanja poduzeća, te istraživanja postojanja mogućih razlika u odnosu na primjenu MRS-a 18 Prihodi, oblikovale jednostavni model na primjeru softverskog poduzeća koje pruža profesionalne usluge kupcima. Rezultati istraživanja su pokazali kako primjena MSFI-ja 15 u odnosu na MRS 18, može rezultirati drugačijim vremenom priznavanja prihoda, što utječe na računovodstvene kategorije u bilanci i računu dobiti i gubitka u kratkom roku (Brozović \& Pavić, 2018., 1019). To, posljedično, utječe na pokazatelje likvidnosti, zaduženosti, aktivnosti, ekonomičnosti i profitabilnosti poslovanja poduzeća (Brozović \& Pavić, 2018., 1019). Iako, u konačnici, u dugom roku razlike u vremenu priznavanja prihoda nestaju, one ipak mogu značajno utjecati na donošenje poslovnih odluka i iskorištavanje poslovnih prilika u kratkom roku, i to u određenim vrstama poduzeća, odnosno industrija (Brozović \& Pavić, 2018., 1019).

Temeljem teorijske analize izazova primjene MSFI-ja 15 Prihodi na temelju ugovora s kupcima, autorica Pavić (2018., 206) zaključuje kako izdavanje tako važnog Standarda mora imati posljedice na vrijeme, iznos priznavanja prihoda te na samo poslovanje određenih vrsta poduzeća, pri čemu se mogu očekivati promjene u strategijama formiranja cijena, redefiniranju ugovora s kupcima, poslovnim modelima, kao i povećanja troškova uslijed nužnih promjena u IT sustavima. Uz to, posebice je istaknuto kako će neminovno doći do nužnosti objave dodatnih informacija o prihodima u bilješkama uz financijske izvještaje (Pavić, 2018., 206). 
Autori Davern, et al. (2019.) su istraživali implementaciju MSFI-ja 15 Prihodi na temelju ugovora s kupcima kako bi pružili uvid u perspektive osoba koje trebaju sastaviti financijske izvještaje o izazovima, troškovima i koristima implementacije tog novog i složenog Standarda. Rezultati istraživanja, na uzorku od 143 sastavljača financijskih izvještaja uključenih u implementaciju MSFI-ja 15, su pokazali postojanje značajnih varijacija u pristupima i napretku u implementaciji zahtjeva Standarda (Davern, et al., 2019.).

Autori Boujelben \& Kobbi-Fakhfakh (2020.) su istraživali stupanj usklađenosti poduzeća u telekomunikacijskoj i građevinskoj industriji sa zahtjevima za objavljivanjem sukladno MSFI-ju 15 Prihodi na temelju ugovora s kupcima. Rezultati istraživanja, na uzorku od 22 poduzeća iz Europske unije listanih na burzi, su pokazali kako navedena poduzeća nisu u potpunosti usklađena sa svim zahtjevima za objavljivanjem prema MSFI-ju 15, kao i to da se razina usklađenosti između poduzeća u telekomunikacijskoj i građevinskoj industriji razlikuje (Boujelben \& Kobbi-Fakhfakh, 2020.). Pri tome, uočeno je kako su poduzeća u telekomunikacijskoj industriji usklađenija sa zahtjevima za objavljivanjem prema MSFI-ju 15 od poduzeća iz građevinarske industrije (Boujelben \& Kobbi-Fakhfakh, 2020., 725).

Autori Napier \& Stadler (2020.) su proveli istraživanje, temeljeno na pregledu godišnjih financijskih izvještaja, pisama komentara i provedenih intervjua, o učincima MSFI-ja 15 Prihodi na temelju ugovora s kupcima na uzorku 48 najvećih poduzeća iz devet europskih zemalja prema indeksu STOXX Europe. Rezultati istraživanja su pokazali postojanje računovodstvenih, informacijskih te, $\mathrm{u}$ manjoj mjeri, realnih učinaka na poslovanje poduzeća (Napier \& Stadler, 2020.). Osim uočenih značajnijih učinaka zahtjeva Standarda u nekoliko industrija, a posebice telekomunikacijskoj industriji, općenito je utvrđeno postojanje relativno slabog učinka na priznavanje i mjerenje prihoda u ostalim industrijama (Napier \& Stadler, 2020.). Uz to, došlo je do povećanja objava povezanih sa Standardom, kao i troškova povezanih s razvojem računalnih softvera za praćenje transakcija i identificiranje ispunjenja obveza po ugovorima s kupcima (Napier \& Stadler, 2020., 500-501). Što se tiče informacijskih učinaka, postoji vrlo malo dokaza o tome da su poduzeća iskoristila priliku uvođenja MSFI-ja 15 za dubinsko pregledavanje i revidiranje svojeg poslovanja (Napier \& Stadler, 2020., 500).

\section{IZVORI PODATAKA I METODOLOGIJA ISTRAŽIVANJA}

Kao što je istaknuto u prvom dijelu rada, cilj rada je istražiti i ocijeniti učinke primjene MSFI-ja 15 Prihodi na temelju ugovora s kupcima na kvalitativna poboljšanja informativne vrijednosti objava u vezi prihoda u bilješkama uz financijske 
izvještaje na primjeru poduzeća u Republici Hrvatskoj te ocijeniti kvantitativne učinke primjene Standarda na razinu prezentiranih prihoda. Prema podacima Hrvatske gospodarske komore u Republici Hrvatskoj je u 2019. godini bilo aktivno 160.630 poslovnih subjekata (Hrvatska gospodarska komora, Digitalna komora, n.d.). Temeljem provedenog pregleda literature $u$ istraživanje su uključena četiri područja djelatnosti za koja je utvrđeno da su bila pod najznačajnijim utjecajem uvođenja novog Standarda, a to su Građevinarstvo (F), Prerađivačka industrija (C) u sektorima proizvodnje brodova i plutajućih objekata (3011), čamaca za razonodu i sportskih čamaca (3012), željezničkih lokomotiva i tračničkih vozila (3020), zrakoplova i svemirskih letjelica (3030), vojnih borbenih vozila (3040), zatim Prijevoz i skladištenje (H), te Informacije i komunikacije (J), a koje su zbog specifičnosti podijeljene na IT \& mediji i Telekomunikacije. Uvažavajući činjenicu da su neka za hrvatsko gospodarstvo značajna poduzeća prema veličini klasificirana kao srednje velika poduzeća, populacija istraživanja uključuje velika i srednje velika poduzeća navedenih područja djelatnosti u Republici Hrvatskoj.

Tablica 3. Struktura poduzeća i uzorka velikih i srednje velikih poduzeća u odabranim područjima djelatnosti u Republici Hrvatskoj u 2019. godini

\begin{tabular}{|c|c|c|c|c|c|}
\hline Područje djelatnosti & $\begin{array}{c}\text { Srednje } \\
\text { velika }\end{array}$ & Velika & Ukupno & Uzorak & $\%$ uzorka \\
\hline Građevinarstvo & 128 & 23 & 151 & 9 & $6 \%$ \\
\hline Gradnja vozila & 9 & 6 & 15 & 7 & $47 \%$ \\
\hline Prijevoz & 89 & 27 & 116 & 11 & $9 \%$ \\
\hline Informacije i komunikacije & 44 & 19 & 63 & 12 & $19 \%$ \\
\hline Ukupno & 270 & 75 & 345 & 39 & $11 \%$ \\
\hline
\end{tabular}

Izvor: Financijska agencija, Registar godišnjih financijskih izvještaja, n.d.

Inicijalno kreiran uzorak prema zadanim obilježjima (djelatnost i ostvareni prihodi u 2019. godini) uključivao je 54 poduzeća, međutim 15 poduzeća kao okvir financijskog izvještavanja koristi Hrvatske standarde financijskog izvještavanja te su isključena iz daljnjeg istraživanja. Konačni uzorak poduzeća uključuje 39 srednje velikih i velikih poduzeća u Republici Hrvatskoj koja su u 2019. godini prema ostvarenim prihodima klasificirana kao najveća u promatranom području djelatnosti (Tablica 3). Za navedena poduzeća prikupljeni su financijski i kvalitativni podaci iz godišnjih financijskih izvještaja za tri poslovne godine (2017., 2018. i 2019.) kako bi se mogle ocijeniti pred-implementacijska, implementacijska i post-implementacijska faza uvođenja MSFI-ja 15 Prihodi na temelju ugovora s kupcima. S obzirom da je jedno poduzeće u uzorku u 2019. godini s primjene Hrvatskih standarda financijskog izvještavanja prešlo na primjenu 
Međunarodnih standarda financijskog izvještavanja konačni panel podaci obuhvaćaju 115 opservacija.

Pored primjene induktivne metode kojom se temeljem pojedinačnih podataka donosi zaključak u cjelini, kao i metode apstrakcije kojom su oblikovane varijable obuhvaćene istraživanjem, zatim metode klasifikacije i analize (Zelenika, 1998), u istraživanju je primijenjena metoda kvalitativne analize sadržaja kao bi se utvrdila prisutnost određenih kvalitativnih svojstava te kvantitativna analiza sadržaja radi kvantitativnog iskazivanja odabranih parametara bilješki uz financijske izvještaje analiziranih poduzeća kroz promatrana razdoblja (Žugaj et al., 2006, 113). Prikupljeni podaci su analizirani odgovarajućim metodama deskriptivne i neparametarske statistike (Kruskal-Wallis test).

\section{REZULTATI ISTRAŽIVANJA}

Prosječna vrijednost ukupne imovine u 2019. godini poduzeća obuhvaćenih istraživanjem bila je 1,50 milijardi kuna, a medijalna vrijednost 506 milijuna kuna što ukazuje na značajnu disperziju podataka.

Tablica 4. Prosječna i medijalna vrijednost ukupne imovine, ukupnih prihoda i prosječnog broja zaposlenih $\mathrm{u}$ analiziranim poduzećima prema industriji u 2019. godini (iznosi su u $000 \mathrm{HRK}$ )

\begin{tabular}{|c|c|c|c|c|c|c|}
\hline \multirow{2}{*}{ Industrija } & \multicolumn{2}{|c|}{ Ukupna imovina } & \multicolumn{2}{c|}{ Ukupni prihodi } & \multicolumn{2}{c|}{$\begin{array}{c}\text { Prosječan broj } \\
\text { zaposlenih }\end{array}$} \\
\cline { 2 - 8 } & Prosjek & Medijan & Prosjek & Medijan & Prosjek & Medijan \\
\hline Građevinarstvo & 929.655 & 513.248 & 756.035 & 705.416 & 402 & 352 \\
\hline Gradnja vozila & 567.115 & 398.251 & 276.444 & 141.717 & 397 & 364 \\
\hline Prijevoz & 1.862 .361 & 1.288 .457 & 666.466 & 523.936 & 935 & 381 \\
\hline IT \& mediji & 381.911 & 425.038 & 430.791 & 341.162 & 380 & 376 \\
\hline \multicolumn{7}{|c|}{$\begin{array}{c}\text { Telekomunikacije } \\
6.393 .158 \\
694.213 \\
1.766 .853 \\
531.120 \\
1.053\end{array}$} \\
\hline Ukupno & 1.499 .598 & 505.693 & 784.423 & 517.956 & 665 & 357 \\
\hline
\end{tabular}

Izvor: Izrada autora 
Disperzija je manja kada su u pitanju ukupni prihodi te su poduzeća u prosjeku ostvarila 784 milijuna ukupnih prihoda, a prosječno su imala 665 zaposlenika (Tablica 4). Prema vrijednosti ukupne imovine najveće su industrije telekomunikacija i prijevoza dok su prema ostvarenim ukupnim prihodima najveće industrije građevinarstvo i prijevoz. Poduzeća koja se bave prijevozom u prosjeku imaju najveći broj zaposlenika.

Kao što je istaknuto u prethodnim dijelovima rada, implementacijom MSFI-ja 15 Prihodi na temelju ugovora s kupcima uvodi se jedinstveni model priznavanja prihoda koji je razrađen kroz model pet koraka i primjenjuje se na sve ugovore $\mathrm{s}$ kupcima, a kojem je u konačnici cilj pružanje relevantnijih informacija korisnicima financijskih izvještaja. S obzirom da je novi Standard zamijenio dva najznačajnija Standarda za priznavanje prihoda, MRS 11 Ugovori o izgradnji i MRS 18 Prihodi, za očekivati je da će navedene relevantne informacije biti odgovarajuće prezentirane i objavljene u bilješkama uz financijske izvještaje.

U skladu s Međunarodnim revizijskim standardima (dalje u tekstu: MRevS), tj. prema točki 30. MRevS-a 700 (izmijenjen) Formiranje mišljenja i izvješćivanje o financijskim izvještajima revizor treba priopćiti ključna revizijska pitanja za revizije cjelovitog skupa financijskih izvještaja opće namjene listanih subjekata u skladu s MRevS-om 701 Priopćavanje ključnih revizijskih pitanja u izvješću neovisnog revizora (Hrvatska revizorska komora, MRevS, n.d.).

Tablica 5. Objavljivanje ključnih revizijskih pitanja u izvješću neovisnog revizora analiziranih poduzeća prema industriji u 2017., 2018. i 2019. godini

\begin{tabular}{|c|c|c|c|c|c|c|c|c|c|c|c|c|}
\hline \multirow{2}{*}{ Industrija } & \multicolumn{4}{|c|}{2017} & \multicolumn{4}{|c|}{2018} & \multicolumn{4}{|c|}{2019} \\
\hline & (1) & (2) & (3) & (4) & (1) & (2) & (3) & (4) & (1) & (2) & (3) & (4) \\
\hline Građevinarstvo & 2 & 2 & 2 & 0 & 1 & 2 & 1 & 0 & 2 & 2 & 0 & 1 \\
\hline Gradnja vozila & 2 & 2 & 1 & 0 & 2 & 2 & 1 & 1 & 2 & 2 & 2 & 2 \\
\hline IT \& mediji & 1 & 2 & 0 & 0 & 1 & 2 & 1 & 0 & 1 & 2 & 1 & 0 \\
\hline Prijevoz & 7 & 2 & 2 & 0 & 7 & 2 & 2 & 1 & 8 & 2 & 3 & 0 \\
\hline Telekomunikacije & 3 & 2 & 0 & 0 & 3 & 2 & 3 & 2 & 4 & 3 & 3 & 0 \\
\hline Total & 15 & 1 & 5 & 0 & 14 & I & 8 & 4 & 17 & 1 & 9 & 3 \\
\hline
\end{tabular}

\section{Legenda:}

1) izvješće neovisnog revizora sadrži ključna revizijska pitanja

2) prosječan broj ključnih revizijskih pitanja u izvješćima neovisnog revizora koja sadrže ključna revizijska pitanja

3) jedno od ključnih revizijskih pitanja povezano je s priznavanjem prihoda

4) ključno revizijsko pitanje koje je povezano s priznavanjem prihoda poziva se na MSFI 15 Prihodi na temelju ugovora s kupcima

Izvor: Izrada autora 
Poduzeća u uzorku koja nisu kotirajući subjekti ili subjekti od javnog interesa nemaju odjeljak ključnih revizijskih pitanja u izvješću neovisnog revizora, a takvih je u prosjeku oko 55\% (2017.: 21/38; 2018.: 22/38; 2019.: 22/39). Od poduzeća koja u izvješću neovisnog revizora imaju odjeljak ključnih revizijskih pitanja može se primijetiti trend povećanja udjela izvješća s uključenim ključnim revizijskim pitanjem u vezi s prihodima (Tablica 5). U godini koja je prethodila implementaciji (2017.) MSFI-ja 15, 33\% (5/15) izvješća je uključivalo ključno revizijsko pitanje u vezi priznavanja prihoda, u godini implementacije (2018.) taj udio je povećan na 57\% (8/14), a u post-implementacijskoj godini (2019.) udio je 52\% (9/17). Također, od ukupnog broja izvješća s uključenim ključnim revizijskim pitanjem u vezi priznavanja prihoda, 50\% izvješća iz 2018. godine u objašnjenju se referiralo na MSFI 15, a u 2019. godini to je svega 33\%. Iako se prividno radi o malom uzorku, treba uvažiti činjenicu da uzorak obuhvaća $11 \%$ ukupnog broja poduzeća iz analizirane industrije i to onih najvećih po ostvarenim prihodima.

Tablica 6. Struktura poduzeća prema industriji i objavljenoj informaciji o primjeni MSFI-ja 15 u bilješkama uz financijske izvještaje za pred-implementacijsku (2017.) i implementacijsku (2018.) godinu

\begin{tabular}{|l|c|c|c|c|c|c|c|}
\hline & \multicolumn{3}{|c|}{2017} & \multicolumn{3}{|c|}{2018} \\
\hline Industrija & $\begin{array}{c}\text { Broj } \\
\text { poduzeća }\end{array}$ & $\mathbf{( 1 )}$ & $\mathbf{( 2 )}$ & $\mathbf{( 3 )}$ & $\mathbf{( 1 )}$ & $\mathbf{( 2 )}$ & (3) \\
\hline Građevinarstvo & 9 & 7 & 0 & $78 \%$ & 5 & 1 & $67 \%$ \\
\hline Gradnja vozila & 7 & 3 & 3 & $86 \%$ & 1 & 5 & $86 \%$ \\
\hline Prijevoz & 10 & 2 & 4 & $60 \%$ & 3 & 6 & $90 \%$ \\
\hline IT \& mediji & 5 & 5 & 0 & $100 \%$ & 4 & 1 & $100 \%$ \\
\hline Telekomunikacije & 7 & 7 & 0 & $100 \%$ & 6 & 0 & $86 \%$ \\
\hline Ukupno & 38 & 24 & 7 & $82 \%$ & 19 & 13 & $84 \%$ \\
\hline
\end{tabular}

\section{Legenda:}

(1) da, uz opis MSFI-ja 15 Prihodi na temelju ugovora s kupcima

(2) da, samo navođenje naziva Standarda

(3) Postotak poduzeća u ukupnom broju poduzeća koji najavljuje primjenu MSFI-ja 15

Izvor: Izrada autora

Obveznici primjene MSFI-ja obvezni su u bilješkama uz financijske izvještaje u sklopu dijela bilješki u kojem se prezentira izjava o usklađenosti, osnova izvještavanja i sažetka osnovnih računovodstvenih politika objaviti informacije o 
novim standardima i dopunama standarda koji su primijenjeni i na snazi, zatim informaciju o izmjenama postojećih standarda koje je objavio Odbor i usvojeni su u Europskoj uniji, ali još nisu na snazi, te informaciju o onim standardima koje je objavio Odbor, ali još nisu usvojeni u Europskoj uniji. Prema tome, poduzeća su u 2017. godini bila obvezna najaviti primjenu MSFI-ja 15 kao objavljenog i usvojenog Standarda, a koji još nije na snazi. Od ukupnog broja poduzeća obuhvaćenog istraživanjem njih $82 \%$ je objavilo potrebnu informaciju bilo kroz cjeloviti opis Standarda (63\%) ili samo kroz navođenje njegova naziva (18\%). U prvoj godini implementacije $84 \%$ poduzeća objavilo je informaciju o primjeni novog MSFI-ja 15 (Tablica 6).

Tablica 7. Objava korištene metode prijelaza u bilješkama uz financijske izvještaje analiziranih poduzeća po industriji u godini implementacije MSFI-ja 15 (2018.)

\begin{tabular}{|c|c|c|c|c|c|c|c|}
\hline \multirow[b]{2}{*}{ Industrija } & \multicolumn{3}{|c|}{ Metoda prijelaza } & \multirow[b]{2}{*}{ (1) } & \multirow[b]{2}{*}{ (2) } & \multirow[b]{2}{*}{ (3) } & \multirow[b]{2}{*}{ (4) } \\
\hline & $\mathrm{Ne}$ & Da & $\begin{array}{c}\text { \% da u } \\
\text { ukupnom } \\
\text { broju }\end{array}$ & & & & \\
\hline Građevinarstvo & 6 & 3 & $33 \%$ & 0 & 3 & 5 & $56 \%$ \\
\hline Gradnja vozila & 6 & 1 & $14 \%$ & 0 & 1 & 5 & $71 \%$ \\
\hline Prijevoz & 4 & 5 & $56 \%$ & 0 & 5 & 8 & $89 \%$ \\
\hline IT \& mediji & 4 & 1 & $20 \%$ & 0 & 1 & 3 & $60 \%$ \\
\hline Telekomunikacije & 2 & 5 & $71 \%$ & 1 & 4 & 2 & $29 \%$ \\
\hline Ukupno & 23 & 15 & $41 \%$ & 1 & 14 & 23 & $62 \%$ \\
\hline
\end{tabular}

Legenda:

(1) Retroaktivno na svako prethodno izvještajno razdoblje (potpuni retroaktivni pristup)

(2) Retroaktivno s kumulativnim učinkom (modificirani retroaktivni pristup)

(3) Primjena MSFI 15 nema značajnih utjecaja na financijske izvještaje

(4) Postotak poduzeća u ukupnom broja koja u bilješkama uz financijske izvještaje imaju navedenu izjavu da primjena MSFI 15 nema značajnih utjecaja na financijske izvještaje

Izvor: Izrada autora 
U skladu s Dodatkom C. novog Standarda poduzeća su dužna implementirati MSFI 15 primjenom jedne od dviju metoda navedenih u nastavku (Uredba Komisije (EU) 2016/1905):

- retroaktivno na svako prethodno izvještajno razdoblje prezentirano u skladu s MRS-om 8 Računovodstvene politike, promjene računovodstvenih procjena i pogreške

- retroaktivno s kumulativnim učinkom početne primjene ovog standarda na datum početne primjene.

Nadalje Dodatkom C. točkom C6 utvrđeno je da je subjekt dužan objaviti sve informacije u vezi upotrjebljenih rješenja te $u$ razumnoj mjeri, kvalitativnu procjenu procijenjenog učinka svakog od tih rješenja. Rezultati provedenog istraživanja pokazuju da je svega $41 \%$ analiziranih poduzeća u bilješkama uz financijske izvještaje objavilo informaciju o korištenoj metodi prijelaza, a od tih poduzeća, njih 6 ili 16\% objavilo je bilješku s kvantifikacijom učinka prijelaza na MSFI 15 (Tablica 7). Pred toga, više od $60 \%$ poduzeća obuhvaćenih istraživanjem u bilješkama uz financijske izvještaje ima istaknutu izjavu da primjena novog Standarda neće značajno ili neće uopće utjecati na financijske izvještaje poduzeća.

Tablica 8. Objava metode za mjerenje napretka u bilješkama uz financijske izvještaje u analiziranim poduzećima po industriji u 2019. godini

\begin{tabular}{|c|c|c|c|c|c|}
\hline Industrija & $\begin{array}{c}\text { Nije } \\
\text { objavljena } \\
\text { metoda }\end{array}$ & $\begin{array}{c}\text { Metoda } \\
\text { inputa }\end{array}$ & $\begin{array}{c}\text { Metoda } \\
\text { outputa }\end{array}$ & $\begin{array}{c}\text { Ne, stupanj } \\
\text { dovršenosti }\end{array}$ & $\begin{array}{c}\text { Bilješka - } \\
\text { Ugovor o } \\
\text { izgradnji }\end{array}$ \\
\hline Građevinarstvo & 0 & 2 & 1 & 6 & 4 \\
\hline Gradnja vozila & 1 & 3 & 0 & 3 & 2 \\
\hline Prijevoz & 5 & 0 & 4 & 2 & 0 \\
\hline IT \& mediji & 3 & 0 & 1 & 1 & 0 \\
\hline Telekomunikacije & 5 & 1 & 1 & 0 & 0 \\
\hline Ukupno & 14 & 6 & 7 & 12 & 6 \\
\hline
\end{tabular}

Izvor: Izrada autora

Sukladno MSFI-ju 15 točka 31. poduzeće prihode priznaje „kada (ili u mjeri u kojoj) subjekt ispuni obvezu na činidbu prijenosom obećane robe ili usluge (odnosno, imovine) kupcu“ (Uredba Komisije (EU) 2016/1905). Nadalje, subjekt 
je obvezan u svakom ugovoru utvrditi ispunjava li se obveza u trenutku ili tijekom vremena, a za svaku obvezu koja se ispunjava tijekom vremena subjekt je dužan primijeniti jedinstvenu metodu mjerenja napretka, a u koje su uključene metode inputa i metode outputa. Ako subjekt ispunjava obveze tijekom vremena sukladno točki 123. MSFI-ja 15 obvezan je objaviti primjenjivane metode i način primjene tih metoda te zašto one predstavljaju vjerodostojan prikaz prijenosa robe i usluga (Uredba Komisije (EU) 2016/1905). S obzirom da subjekt za svaki ugovor procjenjuje ispunjava li se obveza u trenutku ili tijekom vremena, računovodstvene politike mogu obuhvaćati jedan ili drugi pristup, ili kombinaciju pristupa, međutim promjena korištene metode za mjerenje napretka smatra se promjenom računovodstvenih procjena u skladu s MRS-om 8 Računovodstvene politike, promjene računovodstvenih procjena i pogreške. Prema rezultatima analize sadržaja izbor metode za mjerenje napretka u 2019. godini objavilo je 13 ili 33\% analiziranih poduzeća (Tablica 8). Poduzeća koja nisu navela izabranu metodu u pravilu se nisu izjasnila u opisu bilješke o priznavanju prihoda ispunjavaju li obveze u trenutku ili tijekom vremena. U velikoj mjeri takva poduzeća u opisu priznavanja prihoda navode samu definiciju prihoda. Pored toga, značajan je broj poduzeća koja u bilješkama uz financijske izvještaje imaju zasebnu bilješku ugovora o izgradnji (15\%) te je još značajniji udio onih poduzeća koji imaju istaknuto da prihode priznaju primjenom metode stupnja dovršenosti (31\%), a koja je prvenstveno u vezi s više nevažećim standardima MRS-om 11 Ugovori o izgradnji i MRS-om 18 Prihodi.

Tablica 9. Prosječne i medijalne vrijednosti te rezultati Kruskal-Wallis testa za ostvarene prihode od prodaje, broj objavljenih vrsta i kategorija prihoda za analizirana poduzeća od 2017. do 2019. godine (iznosi u 000 HRK)

\begin{tabular}{|c|c|c|c|c|c|}
\hline \multicolumn{2}{|c|}{} & 2017. & 2018. & 2019. & $\begin{array}{c}\text { Kruskal-Wallis Test } \\
\text { (p-vrijednost) }\end{array}$ \\
\hline \multirow{2}{*}{$\begin{array}{c}\text { Prihodi od pro- } \\
\text { daje }\end{array}$} & Prosjek & 615.729 & 626.830 & 645.555 & \multirow{2}{*}{0.845} \\
\cline { 2 - 5 } & Medijan & 350.061 & 349.120 & 399.670 & \multirow{2}{*}{0.842} \\
\hline \multirow{2}{*}{$\begin{array}{c}\text { Broj vrsta pri- } \\
\text { hoda }\end{array}$} & Prosjek & 4 & 4 & 4 & \multirow{2}{*}{0.586} \\
\cline { 2 - 5 } & Medijan & 3 & 4 & 4 & 1 \\
\hline $\begin{array}{c}\text { Broj kategorija } \\
\text { prihoda }\end{array}$ & Prosjek & 1 & 1 & 1 & \multirow{2}{*}{} \\
\cline { 2 - 5 } & Medijan & 1 & 1 & 1 & \multicolumn{2}{|c|}{} \\
\hline
\end{tabular}

Izvor: Izrada autora

Analizom ostvarenih prihoda tijekom analiziranog razdoblja, kao i temeljem objavljenih vrsta prihoda i kategorija po kojima su prihodi objavljeni (u najvećem 
broju slučajeva vrsta robe ili usluge te nakon toga zemljopisna regija ako postoji više od jedne kategorije) može se zaključiti da nije bilo značajnih promjena u bilješkama uz financijske izvještaje u pred-implementacijskom u odnosu na post-implementacijsko razdoblje. Naime, za sve analizirane godine u prosjeku su poduzeća objavljivala četiri vrste prihoda prema vrsti robe ili usluge te je u prosjeku to bila jedina kategorija prihoda koju su objavljivali (Tablica 9). Rezultati neparametarskog Kruskal-Wallis testa potvrđuju da nema razlika u rangovima za promatrane varijable u odnosu na analiziranu godinu.

\section{ZAKLJUČAK}

Analizom sadržaja utvrđeno je da u najvećem broju analiziranih poduzeća bilješke uz financijske izvještaje sadrže doista samo nužne usklade u pogledu zahtjeva za objavom koje su generički formulirane, a u određenom broju slučajeva niti to. Pored toga, jedno od analiziranih poduzeća i u 2019. godini poziva se na priznavanje prihoda u skladu s MRS-om 18 Prihodi. Osim u slučaju manjeg broja analiziranih poduzeća, može se zaključiti da ne postoje kvalitativna poboljšanja informativne vrijednosti objava u vezi prihoda u bilješkama uz financijske izvještaje na primjeru srednje velikih i velikih poduzeća iz industrija građevinarstva, gradnje vozila, prijevoza i informacija i komunikacija u Republici Hrvatskoj za prve dvije godine (2018. i 2019.) primjene novog Standarda MSFI 15 Prihodi na temelju ugovora s kupcima. Također, istraživanjem je utvrđeno da nema statistički značajnih kvantitativnih učinka primjene novog Standarda s obzirom na razinu prezentiranih prihoda kao niti u slučaju objavljenih kategorija i vrsta prihoda. Sveukupno može se zaključiti da su promjene primjetne jedino u dijelu bilješki uz financijske izvještaje koje se odnose na sažetak računovodstvenih politika, gdje su poduzeća formalno promatrano, implementirala MSFI 15, međutim u dijelu bilješki u kojima su detaljnije razrađene pozicije iz financijskih izvještaja, $u$ konkretnom slučaju prihoda, gotovo da ne postoje razlike u objavi informacija u 2019. godini u odnosu na 2017. godinu.

\section{LITERATURA}

1. BDO, (2021.), IFRS AT A GLANCE: IFRS 15 Revenue from Contracts with Customers, BDO IFR Advisory Limited, dostupno na: https://www.bdo.global/getmedia/a2c99a4c-87b2-4c30-83bf-1dd388e35e37/IFRS-15_1.aspx, [pristupljeno 8.7.2021.]

2. Boujelben, S., Kobbi-Fakhfakh, S., (2020.), Compliance with IFRS 15 Mandatory Disclosures: An Exploratory Study in Telecom and Construction Sectors, Journal of Financial Reporting and Accounting, 18(4), str. 707- 
3. 728.Brozović, M., Pavić, I., (2018.), Analysis of the Short- and Longterm Effects of the New Revenue Recognition Standard on Companies Providing Professional Services, Proceedings of the $32^{\text {nd }}$ International Business Information Management Association Conference (IBIMA), Sevilla, Spain, str. 1008-1021.

4. Davern, M., Gyles, N., Potter, B., Yang, V., (2019.), Implementing AASB 15 Revenue from Contracts with Customers: The Preparer Perspective, Accounting Research Journal, 32(1), str. 50-67.

5. Deloitte, (2020.), A Roadmap to Applying the New Revenue Recognition Standard, Deloitte Development LLC., December 2020, dostupno na: https:// www.iasplus.com/en/publications/us/roadmap-series/revenue, [pristupljeno 8.7.2021.]

6. Ergüden, A. E., (2020.), Analysis of Tourism Companies Listed in Istanbul Stock Exchange According to IFRS-15 Standart, International Journal of Finance \& Banking Studies, 9(1), str. 47-57.

7. Europska komisija, (2015.), Izvješće Komisije Europskom parlamentu i Vijeću o aktivnostima Zaklade za MSFI, EFRAG-a i PIOB-a tijekom 2014., dostupno na: https://eur-lex.europa.eu/legal-content/HR/ALL/?uri=COM\%3A2015\%3A0461\%3AFIN, [pristupljeno 8.7.2021.]

8. Financijska agencija, Registar godišnjih financijskih izvještaja, http://rgfi. fina.hr/, [pristupljeno 10.7.2021.]

9. Harris, P., (2020.), A Comprehensive Case Study of Construction Accounting: FASB ASC 606 - PART I, Construction Accounting \& Taxation, 30(5), str. 16-23.

10. Hrvatska gospodarska komora, Digitalna komora, https://digitalnakomora. $\mathrm{hr} /$ home, [pristupljeno 10.7.2021.]

11. Hrvatska revizorska komora, Međunarodni revizijski standardi, prijevod, http://www.revizorska-komora.hr/index.php/kodeks-standardi-smjernice/ medjunarodni-revizijski-standardi.html, [pristupljeno 11.7.2021.]

12. Napier, C. J., Stadler, C., (2020.), The Real Effects of a New Accounting Standard: The Case of IFRS 15 Revenue from Contracts with Customers, Accounting and Business Research, 50(5), str. 474-503.

13. Pavić, I., (2018.), Utjecaj aktualnih promjena u standardima na financijsko izvještavanje, Zbornik radova 21. savjetovanja Interna revizija i kontrola, HZRFD, Sekcija internih revizora, Zagreb - Primošten, Republika Hrvatska, str. 195-214.

14. Uredba Komisije (EU) 2016/1905 od 22. rujna 2016. o izmjeni Uredbe (EZ) br. 1126/2008 o usvajanju određenih međunarodnih računovodstvenih standarda u skladu s Uredbom (EZ) br. 1606/2002 Europskog 
parlamenta i Vijeća u pogledu međunarodnog standarda financijskog izvještavanja 15, dostupno na: https://eur-lex.europa.eu/legal-content/HR/ TXT/?uri=CELEX\%3A32016R1905, [pristupljeno 8.7.2021.]

15. Vaicekauskas, D., (2020.), First Time Adoption of IFRS 15 "Revenue from Contracts with Customers": The Case of Lithuanian Listed Companies, Buhalterinès Apskaitos Teorija ir Praktika (Theory and Practice of Accounting), 21(2020), str. 1-14.

16. van Wyk, M., Coetsee, D., (2020.), The Adequacy of IFRS 15 for Revenue Recognition in the Construction Industry, Journal of Economic and Financial Sciences, 13(1), str. 1-12.

17. Zelenika, R., (1998), Metodologija i tehnologija izrade znanstvenog i stručnog djela, Ekonomski fakultet u Rijeci, Rijeka.

18. Žager, K. i suradnici, (2016.), Računovodstvo I - računovodstvo za neračunovođe, HZRFD, Zagreb.

19. Žager, K. i suradnici, (2017.), Analiza financijskih izvještaja: načela - postupci - slučajevi, treće izmijenjeno i dopunjeno izdanje, HZRFD, Zagreb.

20. Žugaj, M., Dumičić, K., Dušak, V., (2006), Temelji znanstvenoistraživačkog rada: Metodologija i metodika, Fakultet organizacije i informatike, Varaždin. 


\author{
Ana Ježovita, PhD \\ University of Zagreb, Faculty of Economics \& Business, Department of Acco- \\ unting, Zagreb, Croatia \\ ajezovita@efzg.hr \\ Petra Halar, MA \\ University of Zagreb, Faculty of Economics \& Business, Department of Acco- \\ unting, Zagreb, Croatia \\ phalar@efzg.hr

\section{Boris Tušek, PhD} \\ University of Zagreb, Faculty of Economics \& Business, Department of Acco- \\ unting, Zagreb, Croatia \\ btusek@efzg.hr
}

\title{
IMPLEMENTATION EFFECTS OF IFRS 15 REVENUE FROM CONTRACTS WITH CUSTOMERS ON FINANCIAL REPORTING TRANSPARENCY OF COMPANIES IN THE REPUBLIC OF CROATIA
}

Received: August 1, 2021

Accepted: October 15, 2021

https://doi.org/10.46458/27121097.2021.27.72

\section{Preliminary communication}

\begin{abstract}
Revenues as an inflow of economic benefits in the form of assets increase or liabilities decrease are in the focus of managerial activities of every profit-oriented company. Meeting the business objectives of most companies is evaluated directly by the revenues level or indirectly by using revenue-based financial indicators like return on assets, profit margin, earnings before interests, operating earnings. From the aspect of external stakeholders, the importance of revenues is evident in independent auditor's reports, where revenue recognition is emphasized as a key audit matter in 27\% of listed companies in the Republic of Croatia in 2019. In the context of considering revenues as a necessary basis in the business decision-making process, the issue of their recognition in accounting is crucial. With
\end{abstract}


the objective to provide a more robust framework for revenue recognition, ease comparisons in industry, with capital markets, economy, and to offer relevant information to financial statements users in notes to financial statements, the International Accounting Standards Board issued new accounting standard in 2014 which establish the principles that an companies shall apply for revenue recognition from contracts with customers, as well as disclosure requirements in notes to financial statements. The aim is to report useful information to users of financial statements about the nature, amount, timing and uncertainty of revenue and cash flows arising from a contract with a customer. After two years of application of IFRS 15 Revenue from Contracts with Customers the question is what are the effects of the Standard on the disclosure of qualitative and quantitative information in the notes to the financial statements and have more transparent and robust revenue recognition rules resulted in changes in business performance? This paper aims to investigate and evaluate the effects of the application of IFRS 15 Revenue from Contracts with Customers on qualitative improvements in the informative value of revenue disclosures in the notes to financial statements in the Republic of Croatia. In addition, this paper aims to evaluate the quantitative effects of the application of the Standard on the level of presented revenues for the same sample of companies. The sample of enterprises includes about forty enterprises of those industries for which the effect of the application of the new Standard was assessed as the most significant (e.g. telecommunications, construction, shipbuilding). The obtained data were analysed by content analysis method and other applicable methods of inferential statistics.

Keywords: revenue recognition, IFRS 15, contracts with customers, business performance, notes to financial statements

JEL: M41 